\title{
GROUND-PENETRATING RADAR, RESISTIVITY AND SPONTANEOUS POTENTIAL INVESTIGATIONS OF A CONTAMINATED AQUIFER NEAR CANCÚN, MEXICO
}

\author{
Philip J. Carpenter, Ryan F. Adams, Melissa Lenczewski \\ Dept. of Geology and Environmental Geosciences, Northern Illinois University, 312 Davis Hall, DeKalb, IL 60115 USA, \\ pjcarpenter@niu.edu,radamslgeology@niu.edu,lenczewski@niu.edu
}

\section{Rosa M. Leal-Bautista}

Centro de Investigación Cientifica de Yucatán, Cancún, Quintana Roo, Mexico, rleal@cicy.mx

\begin{abstract}
Geophysical surveys were made over portions of the Cancún municipal well field in the Yucatán Peninsula of Mexico, approximately $20 \mathrm{~km}$ southwest of the city of Cancún, in order to identify karst conduits that channel contaminated surface waters into the main aquifer. Specifically, ground-penetrating radar (GPR), vertical electrical soundings (VES) and spontaneous potential (SP) surveys were employed to identify these conduits and detect water movement through them.
\end{abstract}

Cancún s municipal water supply has frequently been affected by fecal coliform bacteria and other contaminants. Water supplies are largely derived from highly permeable fractured karst limestone aquifers characterized by rapid transport of microbial and chemical contaminants from the surface to subsurface unconfined and confined aquifers. Quaternary and Tertiary limestone bedrock outcrops across this entire area, which exhibits less than $3 \mathrm{~m}$ of local relief.

Schlumberger array VES were made at two locations.. One sounding revealed a 3-layered structure consisting of a $177 \mathrm{ohm}-\mathrm{m}$ layer $2.1 \mathrm{~m}$ thick, (probably weathered limestone), overlying a high resistivity layer $8.2 \mathrm{~m}$ thick (massive limestone with some small caves), overlying saturated limestone (45 ohm-m). The other sounding could not be successfully inverted due to lateral resistivity variations. Twenty-one GPR profiles were also made with $50-$ and $100-\mathrm{MHz}$ antennas along roads passing through the well field. In the upper $5 \mathrm{~m}$ these profiles reveal cut-and-fill structures and a myriad of diffractions that may represent collapsed and filled sinkholes or solution-enlarged fractures. A major interface delineated by GPR at about 6-8 $\mathrm{m}$ depth probably represents the water table. An unusual transparent zone (absence of GPR reflections) was also visible in one GPR profile made near a surface conduit. This transparent zone was at least $1.5 \mathrm{~m}$ wide and extended over several meters depth. SP measurements near this conduit during a rainstorm revealed a peak-to-peak variation of $16 \mathrm{mV}$, suggesting SP may also be a viable method for mapping subsurface water movement in this well field. The overall implication of this work is that geophysical methods are valuable in delineating recharge points and shallow contaminant pathways, and should be used more extensively in this part of the Yucatán Peninsula to support groundwater investigations.

\section{Introduction}

The municipal water supply for Cancún, in the northeastern Yucatán Peninsula of Mexico, has been degraded often by fecal coliform bacteria and other contaminants. Water supplies for the Yucatán are largely derived from highly permeable fractured karstic limestone characterized by rapid transport of unfiltered microbial and chemical contaminants from the surface to subsurface unconfined and confined aquifers. The objective of this study is to identify geophysical techniques that could be of use in identifying these infiltration conduits.

In early January 2012, a team from Northern Illinois University (NIU) traveled to Cancún, Quintana Roo, Mexico to join scientists from the Centro de Investigación Cientifica de Yucatán (CICY) to perform exploratory geophysical work to identify infiltration conduits. Geophysical techniques were chosen based on instrumentation traveling economically to the study site. The GPR and SP efforts were directed toward identifying specific karst conduits that provide rapid recharge and contaminant pathways that lead from the land surface to the aquifer. VES were used to examine the overall vertical electrical structure of the well field aquifer, and assess lateral heterogeneity that might necessitate 2D resistivity surveys in the future. 


\section{Geological Setting}

The study site is located within a municipal well field near the Cancún International Airport, approximately 20 $\mathrm{km}$ southwest of the city of Cancún. This area lies within the Yucatan northeastern coastal plain (Isphording, 1975) on a low upland between the eastern coastal ridge and swale complex and the Holbox fracture system to the west. Pliocene - Upper Miocene limestone of the Carillo Puerto formation outcrops, or is covered by only a few $\mathrm{cm}$ of soil, beneath thick jungle cover (Smart et al., 2006). The Carillo Puerto formation is over $300 \mathrm{~m}$ thick, overlying largely carbonate ejecta from the Chicxulub impact structure $200 \mathrm{~km}$ to the west. This ejecta, in turn, overlies carbonate Cretaceous and Jurassic units containing evaporites (Perry, 2002).

\section{Hydrogeology, Contaminants and Karst Features}

Groundwater is the only available fresh water source in the northeast Yucatan peninsula. Groundwater resources, however, are under considerable strain from extensive pumping and development along the Caribbean coast, as well as smaller-scale developments directly over and adjacent to the well field. The average recharge rate in the area ranges from $200-500 \mathrm{~mm} / \mathrm{year}$, and regional groundwater flow is presumed to be easterly beneath the study area, discharging at the coast, about $25 \mathrm{~km}$ away (Bauer-Gottwein et al., 2011).

The survey area is regarded as a contaminated part of the Cancún municipal well system, which consists of several well fields. Obvious contaminant pathways are open fractures and conduits in the limestone that are directly connected to the shallow drinking water aquifer. There isn't significant soil on the surface to allow for filtration of contaminants. The most common contamination is related to feces - pathogens, nutrients, etc. This area is not industrial - contaminants are derived from smallscale agriculture, tourism, or residential activities. Refuse is also (unofficially) disposed of in some of these solution openings.

Numerous publications discuss the cave systems of northeast Yucatan, including Thomas (1999), Beddows (2002a, 2002b, 2003) and Smart et al. (2006). The Riviera Maya cave systems, consisting of several long caves $10 \mathrm{~s}$ of $\mathrm{km}$ long and $10 \mathrm{~s}$ of meters wide are the most extensively studied and mapped. Navigable caves have not been identified within the study area, however, despite the common occurrence of small-scale conduits and collapse features (generally less than $1 \mathrm{~m}$ across). visible at the surface. Thus no cave maps exist in the study area.

\section{Methodology}

Three areas were investigated in detail over the southwest Cancún well field, sometimes referred to as the aeropuerto well field (outlined with squares in Figure 1). These sites were near Well (Pozo) 49A (Area 1) and at the intersection of two of the roads used to service the well field (Area 2), and near Well 40 (Area 3). The three areas we investigated geophysically were essentially targets of opportunity: Well 49A was open and being serviced (Area 1), (2) a visible conduit, partially filled with trash and accepting rainwater (Area 3) near the intersection of the well field service road, Well 40 and the Ruta de los Cenotes, and a service road intersection with nearby apparent depressions in the ground surface that may have been filled sinkholes (Area 2). In general geophysical surveys were made along roads. Road "pavement" consists of the limestone bedrock.

Most of surveys involved GPR since this highresolution technique has the potential to identify conduits transmitting contaminants from the surface into the aquifer. Reviews of GPR for karst settings may be found in Al-fares et al. (2002) and Anchuela et al.

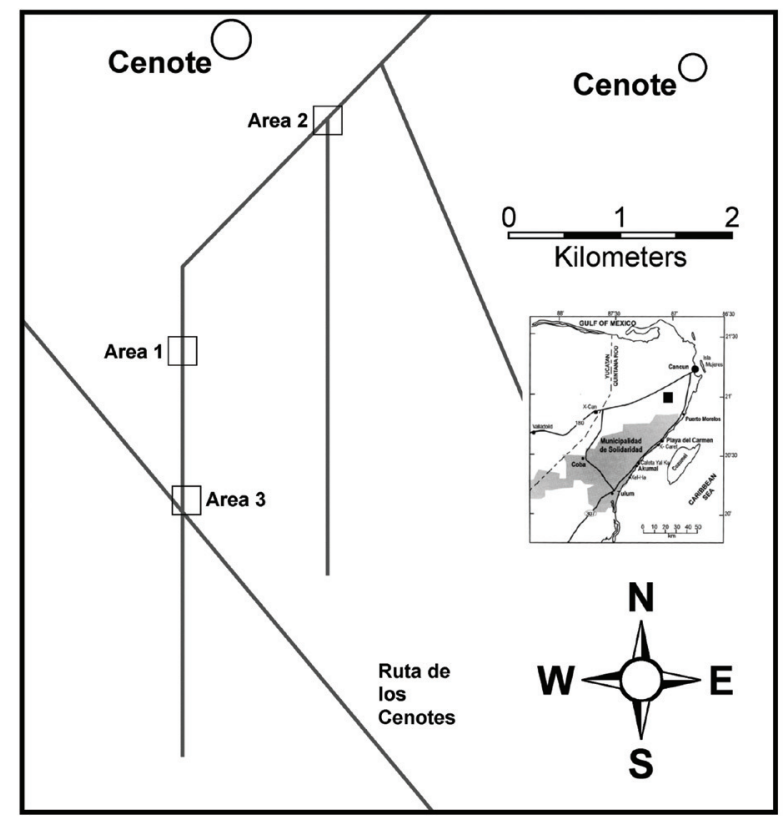

Figure 1. Map of study areas showing roads and cenotes. Inset shows location of study area within the NE Yucatán (inset after Beddows, 2003). 
(2009). The GPR unit used was a Sensors and Software pulseEKKO IV, with 50, 100 and $200 \mathrm{MHz}$ antennas. A total of 21 GPR surveys were made, including three common-midpoint (CMP) surveys to determine GPR wave velocity and 18 profiles of various lengths. All surveys were along straight lines, although some lines were run parallel to each other to examine the areal extent of certain features. Profile lengths ranged from 4 to $40 \mathrm{~m}$. Antenna separation depended on antenna frequency and antennas were manually moved along profiles in $10 \mathrm{~cm}$ increments. In the GPR sections depth is computed from average GPR wave velocity (between 0.09- $0.12 \mathrm{~m} / \mathrm{ns}$ ) determined from the CMP surveys. Shape- matching of diffraction hyperbolas was also used to establish velocity. GPR processing consisted of dewowing (Davis and Annan, 1989), low-pass filtering to reduce high-frequency noise, aligning the air-wave arrival and shifting traces, if necessary, to account for time-zero errors or instrumental drift. Both variablearea and color displays were employed, generally using automatic gain control with a maximum gain of 200. Depths were determined using the average GPR wave velocity measured in the CMP surveys or through diffraction fitting.

The SP and VES surveys were both run from the same system, an ABEM SAS 300B Terrameter (for more information about SP and VES surveys in karst areas see Ford and Williams [2007]). The VES utilized four stainless steel electrodes pounded into the thin topsoil overlying the bedrock in a Schlumberger configuration. SP surveys were made over several intersecting lines near the pumping wells, as well as over apparent karstic conduits (holes visible at the surface) during rainfall. The target was small voltages induced by moving water (streaming potentials) (Reynolds, 2011). Two porous pot electrodes filled with copper sulfate solution were utilized to collect the data. One was fixed as a reference electrode while the other acted as a roving electrode and the unit recorded the difference in potential (in $\mathrm{mV}$ ) between these electrodes. The fixed electrode was at least $10 \mathrm{~m}$ from the roving electrode.

\section{Ground truth calibration}

Very little ground-truth data is available for the study area. The municipal wells for this area were not logged, and any records made during drilling (during the 1970s and 80s) were not immediately available from the Cancún Municipal Water Department. During the geophysical surveys one wellhead had been removed for maintenance (Pozo 49A); the water level in this well was measured at $6.2 \mathrm{~m}$ beneath the surface. It is not known if this water level represents a confined aquifer or not. Most likely it represents the water table, since no apparent confining layers are present. During the 4-day period of the geophysical surveys no maintenance personnel showed up, and the well was left open.

The nearest vertical outcrop is at the Calica quarry, near Playa del Carmen, approximately $30 \mathrm{~km}$ directly south of the study area (Figure 2). The flat lying strata within this area of the Yucatán make this a plausible comparison to the study area.

A heavily weathered zone, approximately $3 \mathrm{~m}$ thick, overlies a massive zone 8-10 m thick, containing caves. The floor of the quarry was wet with some standing water and small ponds, suggesting the water table is at the base of this massive unit, placing the water table approximately 11-13 m beneath the surface. Other wells at Calica penetrate the freshwater/saltwater interface at about $30 \mathrm{~m}$ depth.

\section{Results \\ GPR}

GPR appears to have successfully identified the water table and other layers in the upper $13 \mathrm{~m}$ in Area 1, as shown by Figure 3 (50 MHz antennas). In Area 2 (Figure 4) GPR imaged what appears to be a disrupted zone between depths of 4 and $12 \mathrm{~m}$ containing perhaps the remnants of collapsed caverns and/or sinkholes that have been filled. These appear bowl-shaped or gently

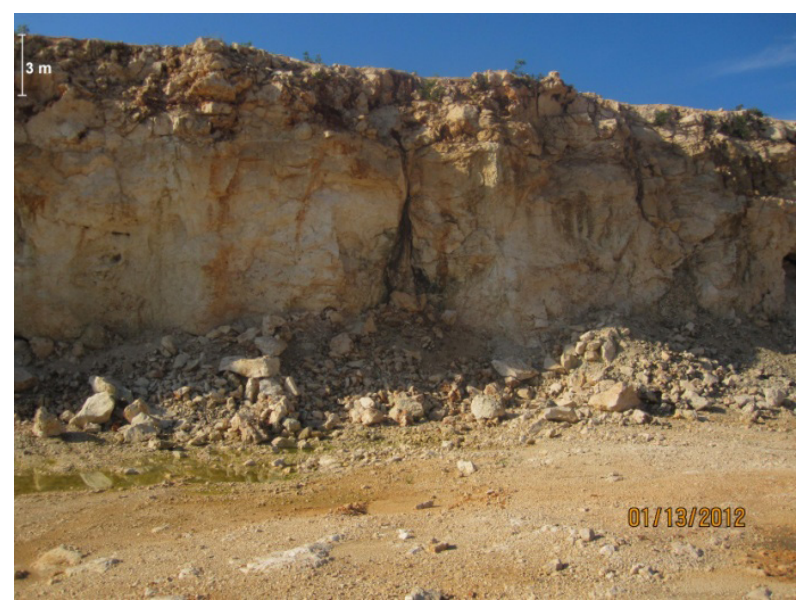

Figure 2. Cross-section of limestone at the Calica quarry, near Playa del Carmen, scale bar is in upper left. 
undulating. Other GPR sections showed steep hyperbolic diffractions, possibly generated by conduits, small caves, or other sharp heterogeneities. Figures 5 and 6 , from Area 3, depict a reflection-free "transparent zone" directly below a surface conduit (a hole at the surface that rainwater was flowing into). This transparent zone may be a largely air-filled conduit producing unusual refraction of GPR waves.

\section{VES}

Schlumberger resistivity arrays were used for VES in Areas 1 and 2 (Figure 7). Electrodes were inserted into the thin soil (zero to $5 \mathrm{~cm}$ thick) covering bedrock. No electrode conditioning was employed.
The VES in Area 1 was interpreted as a 3-layered resistivity model consisting of a $2.1 \mathrm{~m}$ upper layer of resistivity $177 \mathrm{ohm}-\mathrm{m}$, overlying an $8.2 \mathrm{~m}$ thick 465 ohm-m layer, overlying a 45 ohm-m halfspace layer, which probably represents saturated limestone. This structure is consistent with what was observed at Calica (Figure 2), although thicknesses are different. The lower resistivity upper layer is probably highly fractured and weathered limestone, the high-resistivity middle layer may be a compact relatively unweathered limestone and may contain air-filled cavities and voids in its upper portion, as shown in Figure 2, resulting in its elevated resistivity. The lowermost layer probably represents
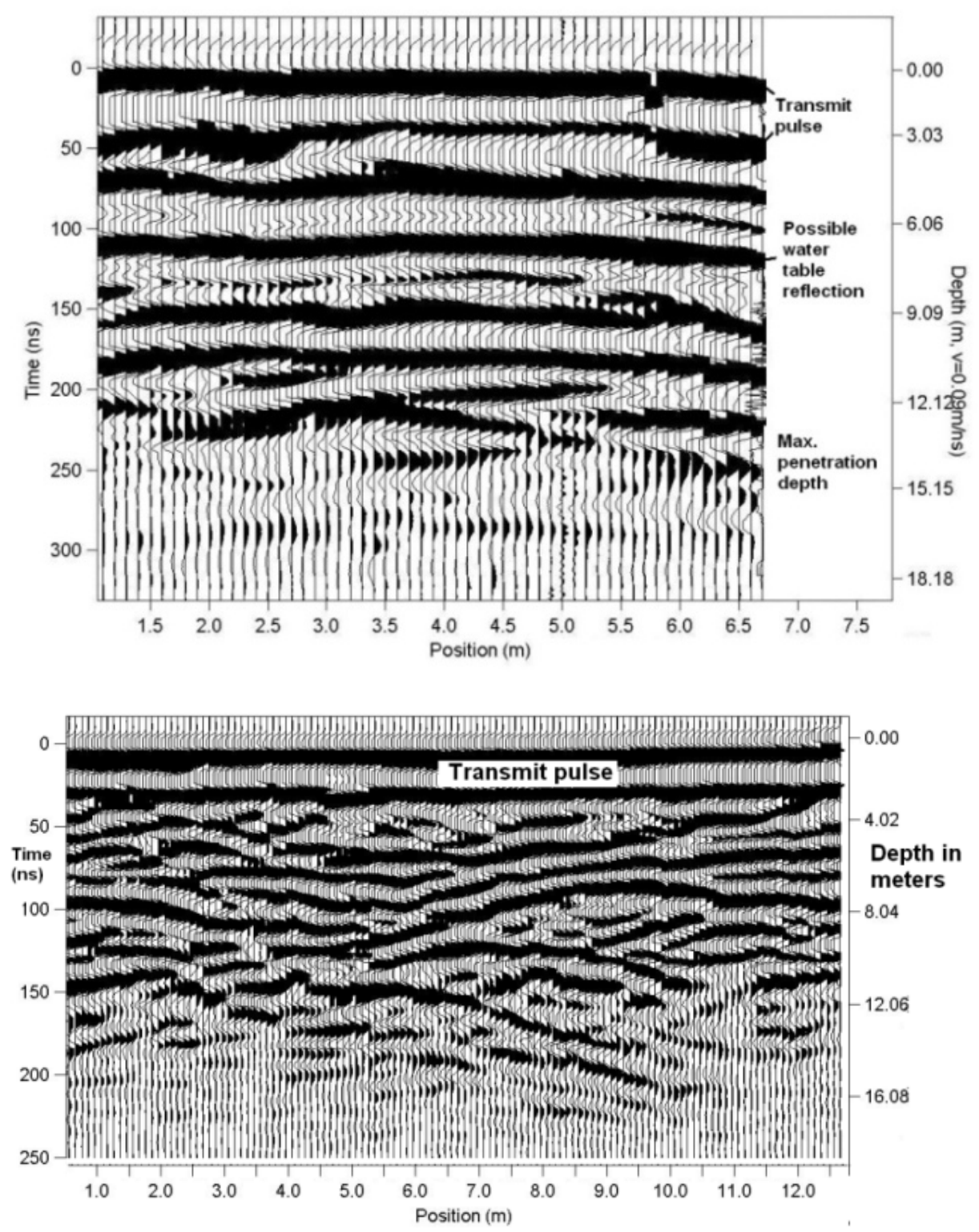

Figure 3. GPR section across part of Area 1. Antenna frequency was 50 $\mathrm{MHz}$, separation $2 \mathrm{~m}$ and the step size between traces $0.1 \mathrm{~m}$.

Figure 4. GPR section across part of Area 2 , showing disrupted reflections and possible collapse features. Antenna frequency was $100 \mathrm{MHz}$, separation $1 \mathrm{~m}$ and the step size between traces $0.1 \mathrm{~m}$. 

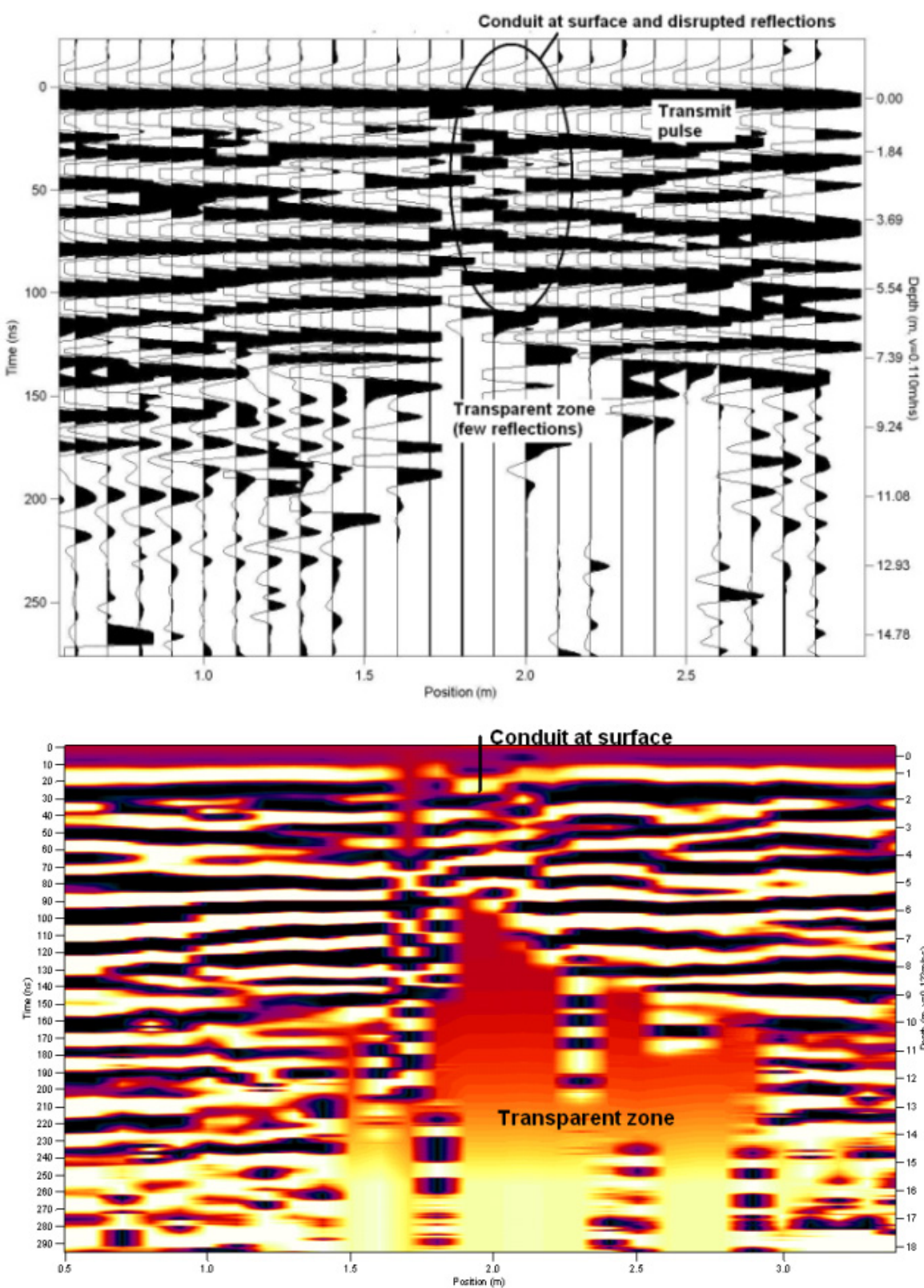

Figure 5. GPR section across part of Area 3. Antenna frequency was $100 \mathrm{MHz}$, separation $1 \mathrm{~m}$ and the step size between traces $0.1 \mathrm{~m}$.
Figure 6. Same GPR section as in Figure 5, but plotted with variable density and in color, to denote areas of signal loss. saturated limestone and/or the saline water zone. The VES in Area 2 was severely affected by lateral resistivity variations and could not be interpreted as a layered model with high confidence. This suggests $2 \mathrm{D}$ resistivity should be employed in future surveys in Area 2.

\section{SP}

SP data was also collected both in Areas 1 and 3 . Several profiles were collected along cross shaped, intersecting lines near the pumping wells. While the lines were not very long, the wells were pumping at a rate of about 1500 liters/min and very little change in the potential was noted. This could be due to the conduit flow nature of the aquifer, i.e. the SP lines might not have passed near the hydraulically active fractures those wells were drawing from (streaming potentials that generate SP are discussed in Reynolds [2011] as well as other geophysical texts). The SP surveys, however, recorded significant changes in potential (about $16 \mathrm{mV}$ ) over a conduit where rainwater was infiltrating, as shown in Figure 8. This fracture was also imaged using GPR in Figures 5 and 6. 

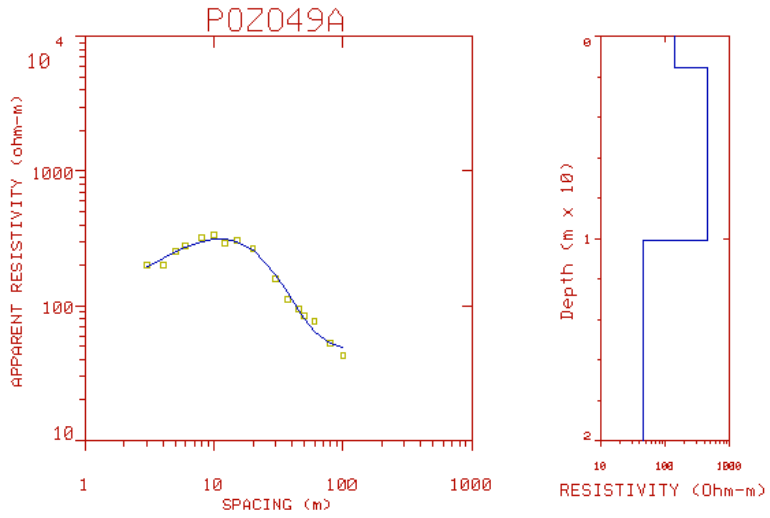

Figure 7. Resistivity sounding made with a Schlumberger array in Area 1, along with the layered model inverted from the sounding curve.

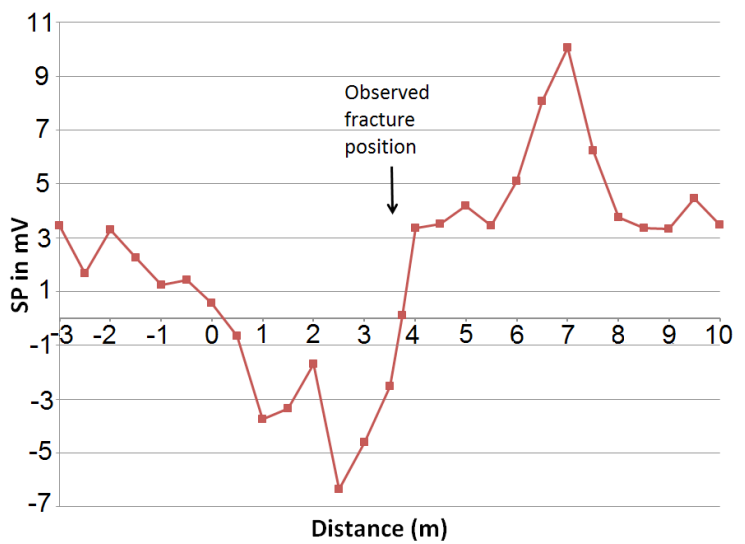

Figure 8. SP profile across a flowing conduit in Area 3.

\section{Conclusions and Future Work}

This study evaluates the feasibility of using geophysical techniques to locate hydraulically conductive infiltration conduits in a karstic aquifer utilized as a water source by the City of Cancún. Three techniques were evaluated: GPR, VES and SP. The water table, at approximately 6-7 $m$ depth, was visible with GPR. VES provided a 3-layer model with a moderate resistivity upper weathered layer overlying a high resistivity layer perhaps representing compact limestone with air-filled voids in its upper part. The lowermost layer was much lower resistivity, suggesting it is below the water table or even in the saline zone. Some GPR profiles also showed apparent (filled) collapse features, as well as transparent zones devoid of reflections. SP surveys worked best across a flowing conduit observed at the surface, where an anomaly of about $16 \mathrm{mV}$ was recorded, presumably due to streaming potentials.

Future work should concentrate surveys over known voids or high permeability zones, so that geophysical models may be verified by ground-truth. Different methods should also be employed that would allow for more expansive and contiguous data sets such as electromagnetic (EM) profiling, conducting GPR using towed antennas, employing very low frequency (VLF) and other systems. This would allow the extent of the conduits to be better characterized and help to understand the complex flow network underground, along with possible contaminant routes.

\section{Acknowledgements}

The authors would like to thank two anonymous reviewers and the Editors whose comments and corrections greatly improved the quality of this manuscript. Travel expenses were paid for, in part by the Mobil Oil Foundation at Northern Illinois University.

\section{References}

Anchuela OP, Casas-Sainz AM, Soriano MA, PocoviJuan A. 2009. Mapping subsurface karst features with GPR: results and limitations. Environ. Geol. 58(2): 391-399. DOI: http://dx.doi.org/10.1007/ s00254-008-1603-7.

Al-fares, Bakalowicz M, Guerin R, Dukhan M. 2002. Analysis of the karst aquifer structure of the Lamalou area (Herault, France) with ground penetrating radar. Jour. Appl. Geophys. 51: 97-106.

Bauer-Gottwein P, Gondwe BRN, Charvet G, Marin LE, Rebolledo-Vieyra M, Merediz-Alonso G. 2011. Review: The Yucatan Peninsula karst aquifer, Mexico. Hydrogeology Journal. DOI: http://dx.doi. org/10.1007/s10040-010-0699-5 (published online)

Beddows PA. 2002a. Where does the sewage go? The karst groundwater system of the Municipalidad de Solidaridad, Quintana Roo, Mexico. Association for Mexican Cave Studies Activities, Houston, TX, p 47-52.

Beddows PA, Smart PL, Whitaker FF, Smith SL. 2002b. Density stratified groundwater circulation on the Caribbean coast of the Yucatan Peninsula, Mexico. In Martin JB, editor. Hydrogeology and biology of postPaleozoic carbonate aquifers, Karst Waters Institute Special Publication 7, p. 129-134.

Beddows PA. 2003. Cave hydrology of the Caribbean Yucatan coast. Bulletin 11, Association of Mexican Cave Studies, Houston, TX, 96 p.

Davis JL, Annan AP. 1989. Ground penetrating radar for mapping of soil and rock stratigraphy. Geophys. Prosp. 37: 531-551.

Ford D, Williams PW. 2007. Karst Hydrogeology and Geomorphology. Chichester (UK): J. Wiley and Sons. 
Isphording WC. 1975. The physical geology of Yucatan. Trans Gulf Coast Assoc Geol Soc 25: 231-262.

Perry E, Velazquez-Oliman G, Marin L. 2002. The hydrogeochemistry of the karst aquifer system of the northern Yucatan Peninsula, Mexico. International Geology Review 44: 191-221.

Reynolds JM. 2011. An Introduction to Applied and Environmental Geophysics. 2nd Ed. Chichester (UK): Wiley-Blackwell.

Smart, PL, Beddows PA, Coke J, Doerr S, Smith S, Whitaker FF. 2006. Cave development on the Caribbean coast of the Yucatan Peninsula, Quintana Roo, Mexico. In: Harmon RS, Wicks C, editors. Perspectives on karst geomorphology, hydrology and geochemistry - a tribute volume to Derek C. Ford and William B. White. Geol. Soc. Am. Special Paper 404. p. 105-128.

Thomas C. 1999. Aspects hydrogéologiques du Yucatan (Mexique) [Hydrogeological aspects of the Yucatan, (Mexico)]. Karstologia 34 (2): 9-22. 
